\title{
A Novel LAMP Assay for the Detection of Phytophthora cinnamomi Utilizing a New Target Gene Identified From Genome Sequences
}

\author{
Tingting Dai, ${ }^{1, \dagger}$ Xiao Yang, ${ }^{2}$ Tao Hu, ${ }^{1}$ Zhongyan $\mathrm{Li},{ }^{1}$ Yue Xu, ${ }^{1}$ and Chenchen $\mathrm{Lu}^{3}$ \\ ${ }^{1}$ College of Forestry, Co-Innovation Center for the Sustainable Forestry in Southern China, Nanjing Forestry University, \\ Nanjing, China \\ ${ }^{2}$ Hampton Roads Agricultural Research and Extension Center, Virginia Tech, Virginia Beach, VA, U.S.A. \\ ${ }^{3}$ Lianyungang Customs (formerly Lianyungang Entry-Exit Inspection and Quarantine Bureau), Lianyungang, China
}

\begin{abstract}
Phytophthora cinnamomi is an ecologically and agriculturally significant plant pathogen. Early and accurate detection of P. cinnamomi is paramount to disease prevention and management. In this study, a loopmediated isothermal amplification (LAMP) assay utilizing a new target gene Pcinn 100006 identified from genomic sequence data was developed and evaluated for the detection of P. cinnamomi. This Pcinn 100006 LAMP assay was found highly specific to $P$. cinnamomi. All 10 tested isolates of $P$. cinnamomi yielded positive results, whereas 50 isolates belonging to 16 other Phytophthora species, Globisporangium ultimum,

DNA of $P$. cinnamomi. In addition, it detected $P$. cinnamomi from artificially inoculated leaves of Cedrus deodara. Moreover, detection rates of $P$. cinnamomi using environmental DNAs extracted from 13 naturally infested rhizosphere samples were $100 \%$ in the Pcinn 100006 LAMP assay versus $46 \%$ in the conventional PCR assay. Considering its higher accuracy and shorter time span, this Pcinn 100006 LAMP assay is a promising diagnostic tool to replace conventional PCR-based and culture-dependent assays for screening of $P$. cinnamomi in regions at risk of infection or contamination.
\end{abstract} and 14 fungal species lacked detection. This assay was 10 times more sensitive (100 pg in a $25-\mu l$ reaction mixture) than a conventional PCR assay ( $2 \mathrm{ng}$ in a $50-\mu \mathrm{l}$ reaction mixture) for detecting the genomic
Keywords: disease diagnosis, hydroxynaphthol blue, oomycetes, Phytophthora root rot, Phytophthora dieback, plant destroyers
Phytophthora species are eukaryotic organisms that resemble filamentous fungi in mycelial growth, but they are phylogenetically related to diatoms and brown algae in the stramenopiles (Dick 2001; Thines and Kamoun 2010). Among many important phytopathogenic Phytophthora species, Phytophthora cinnamomi is a highly aggressive species that affects agriculture, horticulture, and forestry industries as well as natural forests (Erwin and Ribeiro 1996; Rands 1922; Zentmyer 1980). For example, P. cinnamomi causes Phytophthora root rot, a major threat to the worldwide avocado production (Erwin and Ribeiro 1996; Hardham 2005). It also causes root and crown rot and dieback on ornamental crops (Crandall et al. 1945; Duan et al. 2008; Erwin and Ribeiro 1996; Linderman and Zeitoun 1977). In addition, P. cinnamomi is a destructive pathogen threatening many forest tree species (Hardham 2005; Shearer et al. 2004; Zentmyer 1980). Current pathogen control measures rely on application of oomyceticides and soil sanitation. However, the ability of producing oospores, stromata, and chlamydospores in host roots and soil (Crone et al. 2013; McCarren et al. 2005) makes P. cinnamomi a persistent, soilborne pathogen that is difficult to manage (Erwin and Ribeiro 1996).

${ }^{\dagger}$ Corresponding author: T. Dai; 13770647123@163.com

Funding: This work was supported by National Nature Science Foundation of China grant 31500526, China Postdoctoral Science Foundation grant 2016T790467, the Overseas Research and Study Project of Excellent Young and Middle-Aged Teachers and Principals in Colleges and Universities of Jiangsu Province of 2018, and The Priority Academic Program Development of Jiangsu Higher Education Institutions.

*The $\boldsymbol{e}$-Xtra logo stands for "electronic extra" and indicates that one supplementary table is published online.

The author(s) declare no conflict of interest.

Accepted for publication 26 June 2019.

C 2019 The American Phytopathological Society
Early detection is the first and most important step in the management of $P$. cinnamomi diseases. Many molecular genetic assays, such as conventional PCR, nested PCR, and quantitative PCR (qPCR), have been designed for detecting $P$. cinnamomi. Specifically, Kong et al. (2003) developed a P. cinnamomi-specific nested PCR assay using primers derived from the $L p v$ genes. Engelbrecht et al. (2013) also used primers amplifying the $L p v$ genes in a nested qPCR assay for diagnosing Phytophthora root rot on avocado rootstocks. Schena et al. (2008) and Trzewik et al. (2016) designed P. cinna$m o m i$-specific primer pairs (Ycin3F\&4R and Pcin59F\&191R, respectively) based on the Ypt 1 gene. Langrell et al. (2011) and Williams et al. (2009) developed two nested PCR assays for detecting $P$. cinnamomi in soil, both targeting the internal transcribed spacer (ITS) region. Miles et al. (2015) designed primers targeting the atp9-nad9 genetic marker in a qPCR assay. However, Kunadiya et al. (2017) evaluated the aforementioned assays plus two additional qPCR assays targeting the ITS region. Among eight evaluated assays, only three were specific to $P$. cinnamomi (Kunadiya et al. 2017). The other five assays failed in differentiating $P$. cinnamomi from Phytophthora parvispora (Kunadiya et al. 2017), a species closely related to $P$. cinnamomi (Scanu et al. 2014; Yang et al. 2017).

Loop-mediated isothermal amplification (LAMP) of DNA (Notomi et al. 2000), an emerging technique used in the detection of pathogens, has several advantages in comparison with conventional PCR. It usually has high specificity by using a set of four or six species-specific primers (Notomi et al. 2000). Another advantage is its low requirement for resources. LAMP produces large quantities of replicate DNA using the Bst DNA polymerase without thermal cycling. It is performed under isothermal conditions ranging from 60 to $65^{\circ} \mathrm{C}$ (Notomi et al. 2000). Furthermore, LAMP assays can be finished in $1 \mathrm{~h}$ (Notomi et al. 2000), which is half the time of a typical 30-cycle PCR reaction. Results of LAMP assays can be assessed by color when analytical dyes are added to the reaction mixture. Specifically, the addition of hydroxynaphthol blue (HNB) to the reagent mixture before reaction avoids the risks of contamination and subsequent false positives associated with postreaction addition of dyes (Goto et al. 2009). Several LAMP assays have been developed for rapid detection of Phytophthora species, including Phytophthora 
capsici (Dong et al. 2015), Phytophthora infestans (Hansen et al. 2016; Khan et al. 2017; Si Ammour et al. 2017), Phytophthora kernoviae (Miles et al. 2015; Tomlinson et al. 2010), Phytophthora melonis (Chen et al. 2013), Phytophthora nicotianae (Li et al. 2015), Phytophthora ramorum (Miles et al. 2015; Tomlinson et al. 2007, 2010), Phytophthora sansomeana (Rojas et al. 2017), and Phytophthora sojae (Dai et al. 2012; Rojas et al. 2017; Zhao et al. 2015). No P. cinnamomispecific LAMP assay has been developed before this study.

The objective of this study was to develop an LAMP assay for the detection of $P$. cinnamomi in plant tissues and environmental samples. $P$. cinnamomi-specific primers were designed to amplify a novel target identified from comparison of genomic sequence data. Both specificity and sensitivity of the novel LAMP assay were evaluated in this study.

\section{Materials and Methods}

Selection and maintenance of isolates. A total of 60 isolates (Table 1), including 10,34, one, and 15 isolates belonging to $P$. cinnamomi, other Phytophthora species, Globisporangium ultimum, and fungal species, respectively, were used in this study. Oomycete and fungal cultures were grown at $25^{\circ} \mathrm{C}$ in $20 \%$ clarified V8 juice agar (cV8A) and potato dextrose agar, respectively.

DNA extraction. Mycelial masses of oomycete and fungal isolates were produced by growing cultures in $20 \%$ clarified V8 juice broth and potato dextrose broth, respectively, at $25^{\circ} \mathrm{C}$ for 3 to 5 days. They were harvested by filtration and then, frozen at $-20^{\circ} \mathrm{C}$. Genomic DNAs (gDNAs) were extracted using a DNAsecure Plant Kit (Tiangen Biotech). Concentrations of gDNAs were determined using a NanoDrop 2000c spectrophotometer (NanoDrop Technologies). Quantified gDNA extractions were stored at $-20^{\circ} \mathrm{C}$.

A modified method of Wang et al. (1993) was used to extract DNA from plant tissues in this study. Leaf surfaces were cleaned in distilled water and sterilized by immersing the leaves in $70 \%$ ethanol for $30 \mathrm{~s}$. Approximately $100 \mathrm{mg}$ of leaf tissue was added into a 1.5-ml centrifuge tube. A sterile pellet pestle was used to grind the leaf tissue until no large pieces of plant issues were visible, whereas $1 \mathrm{ml}$ of $0.5 \mathrm{M} \mathrm{NaOH}$ solution $(10 \mu \mathrm{l} / \mathrm{mg}$ of plant tissue) was gradually added to the tube. Five microliters of ground sample was immediately transferred to a new tube containing $495 \mu$ of Tris buffer $(100 \mathrm{mM}$, $\mathrm{pH}$ 8.0). The mixture was used as a template in the following assays

LAMP primer design. To select candidate target genes for $P$. cinnamomi-specific LAMP reaction, the annotated genomic sequence of $P$. cinnamomi at https://genome.jgi.doe.gov/Phycil/Phycil.home. html (Nordberg et al. 2014) was retrieved. All 26,131 gene sequences of $P$. cinnamomi were used as queries to blast against several other publicly available genomic sequences of Phytophthora species (E-value cutoff: $1 \mathrm{e}^{-5}$ ) at the respective portals, including P. capsici (https://genome.jgi.doe.gov/PhycaF7/PhycaF7.home.html),

Table 1. Isolates of the genus Phytophthora and other oomycete and fungal species used in this study to determine the specificity of the Pcinn100006 loopmediated isothermal amplification (LAMP) assay

\begin{tabular}{|c|c|c|c|c|}
\hline (Sub-)clade ${ }^{\mathrm{a}}$ and species & Isolate $^{\mathbf{b}}$ & Host or substrate & Location & LAMP result $\mathrm{c}^{\mathrm{C}}$ \\
\hline \multicolumn{5}{|l|}{$7 \mathrm{c}$} \\
\hline Phytophthora cinnamomi & Pci1 & Pinus sp. & Anhui, China & + \\
\hline Phytophthora cinnamomi & Pci2 & Rhododendron simsii & Jiangsu, China & + \\
\hline Phytophthora cinnamomi & Pci3 & Cedrus deodara & Jiangsu, China & + \\
\hline Phytophthora cinnamomi & Pci4 & Camellia oleifera & Jiangsu, China & + \\
\hline Phytophthora cinnamomi & Pci5 & Pinus sp. & Jiangsu, China & + \\
\hline Phytophthora cinnamomi & Pci6 & Rhododendron simsii & Anhui, China & + \\
\hline Phytophthora cinnamomi & Pci7 & Rhododendron simsii & Shangdong, China & + \\
\hline Phytophthora cinnamomi & Pci8 & Cedrus deodara & Shangdong, China & + \\
\hline Phytophthora cinnamomi & Pci9 & Cedrus deodara & Anhui, China & + \\
\hline Phytophthora cinnamomi & Pcilo & Pinus sp. & Shangdong, China & + \\
\hline Phytophthora parvispora & CBS132771 & Arbutus unedo & Italy & - \\
\hline \multicolumn{5}{|l|}{$7 \mathrm{a}$} \\
\hline Phytophthora rubi & CBS 967.95 & Rubus sp. & U.S.A. & - \\
\hline Phytophthora cambivora & CBS 248.60 & Castanea sativa & U.S.A. & - \\
\hline \multicolumn{5}{|l|}{$7 \mathrm{~b}$} \\
\hline Phytophthora melonis & PMNJHG1 & Cucumis sativus & Jiangsu, China & - \\
\hline Phytophthora melonis & PMNJHG2 & Cucumis sativus & Jiangsu, China & - \\
\hline Phytophthora melonis & PMNJHG3 & Cucumis sativus & Jiangsu, China & - \\
\hline Phytophthora melonis & PMNJDG1 & Benincasa hispida & Jiangsu, China & - \\
\hline Phytophthora melonis & PMNJDG2 & Benincasa hispida & Jiangsu, China & - \\
\hline Phytophthora melonis & PMNJDG3 & Benincasa hispida & Jiangsu, China & - \\
\hline Phytophthora melonis & PMFJHL1 & Lagenaria siceraria & Fujiang, China & - \\
\hline Phytophthora melonis & IMI 325917 & Cucumis sp. & Fujiang, China & - \\
\hline Phytophthora sojae & P6497 & Glycine max & Mississippi, U.S.A. & - \\
\hline Phytophthora sojae & R3 & Glycine max & Fujiang, China & - \\
\hline \multicolumn{5}{|l|}{1} \\
\hline Phytophthora cactorum & $\mathrm{C} 1$ & Malus pumila & Jiangsu, China & - \\
\hline Phytophthora cactorum & $\mathrm{C} 2$ & Malus pumila & Jiangsu, China & - \\
\hline Phytophthora cactorum & $\mathrm{C} 3$ & Rosa chinensis & Jiangsu, China & - \\
\hline Phytophthora infestans & Pi1 & Solanum tuberosum & Fujiang, China & - \\
\hline Phytophthora infestans & Pi2 & Solanum tuberosum & Yunnan, China & - \\
\hline Phytophthora nicotianae & Pn1 & Nicotiana tabacum & Fujiang, China & - \\
\hline Phytophthora nicotianae & Pn2 & Lycopersicum sp. & Jiangsu, China & - \\
\hline Phytophthora nicotianae & Pn3 & Sophora sinensis & Jiangsu, China & - \\
\hline Phytophthora nicotianae & Pn4 & Citrus sp. & Jiangsu, China & - \\
\hline
\end{tabular}

a Molecular phylogenetic (sub-)clade of Phytophthora species as indicated by Yang et al. (2017).

b Isolate identification abbreviations: ATCC, American Type Culture Collection, Manassas, Virginia, U.S.A.; CBS, Centraalbureau voor Schimmelcultures Fungal Biodiversity Centre, Utrecht, The Netherlands; IMI, CABI Biosciences, United Kingdom.

${ }^{c}$ Only genomic DNAs of $P$. cinnamomi isolates could be detected using the Pcinn100006 LAMP assay, indicating high specificity. -, negative; +, positive. 
P. infestans (https://genome.jgi.doe.gov/Phyinf1/Phyinf1.home.html), P. nicotianae (= Phytophthora parasitica; https://www.ncbi.nlm.nih. gov/genome/11752), P. ramorum (https://genome.jgi.doe.gov/Phyra1_ 1/Phyra1_1.home.html), and P. sojae (https://genome.jgi.doe.gov/ Physo3/Physo3.home.html). They were also used to blast against several unpublished genomic sequences (B. M. Tyler, unpublished data) of Phytophthora asiatica (= P. cinnamomi var robiniae), $P$. parvispora (= P. cinnamomi var parvispora), and Phytophthora vignae using SeqHunter2 (https://sourceforge.net/projects/seqhunter2/files). We found that 1,515 genes of $P$. cinnamomi lacked homologs with genomic sequences of other species. Five loci (Supplementary Table S1), namely Pcinn100006 (387 nucleotides [nt]), Pcinn100532 (724 nt), Pcinn10079 (822 nt), Pcinn10160 (156 nt), and Pcinn1025 (255 nt), were randomly selected among those of adequate sizes for designing LAMP primers. Primers were designed using PrimerExplorer V4 at http://primerexplorer.jp/e/ (Eiken Chemical Co., Ltd.) and synthesized by Invitrogen Trading Shanghai Co., Ltd. Individual sets of primers were evaluated based on the LAMP amplicon yield by visually estimating color intensity (Goto et al. 2009) or turbidity (Mori et al. 2001) with or without the addition of HNB, respectively. A set of four LAMP primers amplifying six distinct DNA target regions of the single-copy Pcinn100006 gene plus a pair of loop-forward and back-forward primers accelerating LAMP amplification were selected. Sequences of these primers used in the Pcinn 100006 LAMP assay are listed in Table 2.

LAMP reaction. LAMP reaction mixtures with prereaction addition of HNB (Sigma-Aldrich) were optimized in preliminary tests by adjusting the concentration of reagents and incubation duration. The optimal $25-\mu$ l reaction included $2.5 \mu \mathrm{l}$ of $10 \times$ ThermoPol buffer
(New England Biolabs), $2.25 \mu$ l each of forward inner primer (FIP) and backward inner primer (BIP) $(1.8 \mu \mathrm{M})$ (Table 2), $1 \mu$ l each of F3 and B3 (0.4 $\mu \mathrm{M})$ (Table 2) as well as loop forward (LF) and loop backward (LB) $(0.8 \mu \mathrm{M})$ (Table 2), $2 \mu \mathrm{l}$ of betaine $(0.8 \mathrm{M}), 3 \mu \mathrm{l}$ each of dNTPs $(1.2 \mathrm{mM})$ and $\mathrm{MgSO}_{4}(6 \mathrm{mM}), 2 \mu \mathrm{l}$ of $\mathrm{HNB}(180 \mathrm{mM}), 1 \mu \mathrm{l}$ of $B s t$ DNA polymerase (8 U/ $\mu \mathrm{l}$; New England Biolabs), $2 \mu \mathrm{l}$ of DNA template, and $1 \mu \mathrm{l}$ of nuclease-free $\mathrm{H}_{2} \mathrm{O}$. The reaction mixture was incubated in a water bath set at $64^{\circ} \mathrm{C}$ for $60 \mathrm{~min}$. Each set of reactions included a control known to yield a positive detection result (100 ng of purified gDNA of P. cinnamomi isolate Pcil as template) and a nontemplate control (NTC; DNA template replaced by nuclease-free $\mathrm{H}_{2} \mathrm{O}$ ). LAMP results were visualized by the naked eye and determined by color change (Goto et al. 2009). Reactions that turned blue were positive, indicating the presence of Pcinn 100006 specific to $P$. cinnamomi. Those that remained violet were negative, indicating the lack of detection of Pcinn100006.

Detection of $P$. cinnamomi using a conventional PCR assay. Primers F3 and B3 (Table 2) designed for the LAMP assay were also used to amplify the Pcinn100006 gene in a conventional PCR assay. The 50- $\mu$ l PCR reaction mixture included $2 \mu l$ of purified gDNA (or $4 \mu \mathrm{l}$ of DNA extracted from soil and leaf samples), $25 \mu \mathrm{l}$ of PrimerSTAR Max Premix (2x; Takara Shuzo), $1 \mu$ l each of primers F3 and B3 $\left(10 \mu \mathrm{M}\right.$ ), and $21 \mu \mathrm{l}$ of nuclease-free $\mathrm{H}_{2} \mathrm{O}$ (or $19 \mu \mathrm{l}$ for soil and leaf samples). The thermal cycling program was carried out at $95^{\circ} \mathrm{C}$ for $4 \mathrm{~min}$ and 32 cycles of $95^{\circ} \mathrm{C}$ for $10 \mathrm{~s}, 56^{\circ} \mathrm{C}$ for $5 \mathrm{~s}$, and $72^{\circ} \mathrm{C}$ for $5 \mathrm{~s}$ followed by $72^{\circ} \mathrm{C}$ for 5 min using an Applied Biosystems Veriti Dx 96-Well Thermal Cycler (Thermo Fisher Scientific). Each set of reactions included a control known to be positive (200 ng of purified gDNA of P. cinnamomi isolate Pcil as template) and an

Table 1. (Continued from previous page)

\begin{tabular}{|c|c|c|c|c|}
\hline (Sub-)clade ${ }^{\mathrm{a}}$ and species & Isolate $^{b}$ & Host or substrate & Location & LAMP result ${ }^{c}$ \\
\hline \multicolumn{5}{|l|}{2} \\
\hline Phytophthora capsici & $\mathrm{Pc} 1$ & Capsicum аппиит & Jiangsu, China & - \\
\hline \multicolumn{5}{|l|}{4} \\
\hline Phytophthora palmivora & Pp1 & Iridaceae & Yunnan, China & - \\
\hline \multicolumn{5}{|l|}{6} \\
\hline Phytophthora megasperma & CBS 305.36 & Matthiola incana & U.S.A. & - \\
\hline \multicolumn{5}{|l|}{8} \\
\hline Phytophthora drechsleri & CBS 292.35 & Beta vulgaris var altissima & California, U.S.A. & - \\
\hline Phytophthora drechsleri & ATCC 56353 & Citrus sinensis & Australia & - \\
\hline Phytophthora hibernalis & CBS 270.31 & Citrus sinensis & U.S.A. & - \\
\hline Phytophthora syringae & ATCC 34002 & Citrus sp. & California, U.S.A. & - \\
\hline Phytophthora ramorum & ATCC MYA-2949 & Quercus agrifolia & California, U.S.A. & - \\
\hline \multicolumn{5}{|l|}{10} \\
\hline Phytophthora boehmeriae & $\mathrm{Pb} 1$ & Boehmeria nivea & Jiangsu, China & - \\
\hline Phytophthora boehmeriae & $\mathrm{Pb} 2$ & Gossypium sp. & Jiangsu, China & - \\
\hline Phytophthora boehmeriae & $\mathrm{Pb} 3$ & Boehmeria nivea & Jiangsu, China & - \\
\hline Phytophthora boehmeriae & $\mathrm{Pb} 4$ & Gossypium sp. & Jiangsu, China & - \\
\hline \multicolumn{5}{|l|}{ Genus Globisporangium } \\
\hline Globisporangium ultimum & Gu1 & Irrigation water & Jiangsu, China & - \\
\hline \multicolumn{5}{|l|}{ Fungi } \\
\hline Alternaria alternata & LH1401 & Cucumis melo & Jiangsu, China & - \\
\hline Aspergillus oryzae & Ao1 & Glycine max & Jiangsu, China & - \\
\hline Cercospora kikuchii & Ck1 & Glycine $\max$ & Jiangsu, China & - \\
\hline Colletotrichum gloeosporioides & $\mathrm{Cg} 1$ & Glycine max & Jiangsu, China & - \\
\hline Colletotrichum truncatum & $\mathrm{Ct} 1$ & Glycine $\max$ & Jiangsu, China & - \\
\hline Diaporthe phaseolorum var caulivora & DPC & Glycine $\max$ & Jiangsu, China & - \\
\hline Fusarium equiseti & $\mathrm{Fe} 1$ & Pinus sp. & Jiangsu, China & - \\
\hline Fusarium oxysporum & Fo1 & Pinus sp. & Jiangsu, China & - \\
\hline Fusarium solani & Fs1 & Gossypium sp. & Jiangsu, China & - \\
\hline Fusarium solani & Fs2 & Glycine max & Jiangsu, China & - \\
\hline Magnaporthe grisea & Guy11 & Oryza sativa & French Guiana & - \\
\hline Nigrospora sphaerica & Ns1 & Glycine $\max$ & Jiangsu, China & - \\
\hline Phakopsora pachyrhizi & Pa1 & Glycine max & Jiangsu, China & - \\
\hline Phomopsis asparagi & Pas1 & Asparagus officinalis & Jiangsu, China & - \\
\hline Rhizoctonia solani & Rs1 & Gossypium sp. & Jiangsu, China & - \\
\hline
\end{tabular}


NTC. After the amplification, PCR products were analyzed by $1.5 \%$ agarose gel electrophoresis at $120 \mathrm{~V}$ for $\sim 30 \mathrm{~min}$. Agarose gel was stained by ethidium bromide and visualized on a transilluminator.

Comparative evaluations of specificity and sensitivity of LAMP and PCR assays. In a comparative evaluation of $P$. cinnamomi specificity, both Pcinn100006 LAMP and conventional PCR assays were performed under the respective optimal conditions as described above. Purified gDNAs (100 ng in the 25- $\mu$ l LAMP reaction; $200 \mathrm{ng}$ in the 50- $\mu$ l PCR reaction) of all 60 isolates (Table 1) were used as templates in both assays. A pair made up of positive control and NTC was included in each set of reactions. All 60 isolates were evaluated twice in each assay.

In a comparative evaluation of sensitivity, seven concentrations of gDNA of $P$. cinnamomi isolate Pcil, including 100, 10, 1, 0.1, 0.01, 0.001 , and $0.0001 \mathrm{ng}$, in every $25 \mu \mathrm{l}$ of reaction mixture were used as templates in both LAMP and conventional PCR assays. An NTC was included in each set of reactions. All template concentrations were evaluated twice in each assay.

Detection of $P$. cinnamomi in artificially inoculated plant samples using LAMP and PCR assays. Needle-like leaves of Cedrus deodara were obtained from a predetermined $P$. cinnamomi-free landscape site at Nanjing Forestry University (NFU), Nanjing, China. A $2 \times 2-\mathrm{mm}$ actively growing mycelial plug of $P$. cinnamomi isolate Pcil grown in cV8A was mixed with $100 \mathrm{~g}$ of $C$. deodara leaves and placed in each of triplicate sterile 250 -ml flasks. A flask containing healthy leaves mixed with a sterile cV8A agar plug was prepared in parallel as a negative control. The flasks were covered using parafilm and placed in an illuminated incubator set at $22^{\circ} \mathrm{C}, 100 \%$ relative humidity, and a 12-h photoperiod for 3 to 5 days. They were shaken daily to avoid clumping as mycelia. Leaves from each flask were then cut into small pieces and subjected to DNA extraction following the modified method of Wang et al. (1993) as described above. Extracted DNAs were used as template in the Pcinn100006
LAMP assay under the optimal condition. This experiment was carried out twice. Purified gDNA (100 ng) of $P$. cinnamomi isolate Pci1 was used as the template in a positive control reaction.

Comparative evaluation of the Pcinn100006 LAMP and PCR assays using $\boldsymbol{P}$. cinnamomi-infested rhizosphere samples. A total of 13 rhizosphere samples were collected from locations in Jiangsu, Anhui, Shandong, Fujian, and Yunnan provinces in China from 2014 to 2017 (Table 3), where P. cinnamomi was isolated from the roots of various plants, including Pinus, Rhododendron, Cedrus, and Camellia species, during preliminary baiting surveys. A soil sample collected from the $P$. cinnamomi-free site at NFU was used as a negative control sample (Table 3). All 14 samples were transferred to the Co-Innovation Center for the Sustainable Forestry in Southern China at NFU and stored at $4^{\circ} \mathrm{C}$ before further processing.

Each sample was mixed well and divided into two equal subsamples. Environmental DNA (eDNA) was directly extracted from each subsample of the first set using the Plant DNA Mini Kit (Omega Biotek). Both Pcinn100006 LAMP and conventional PCR assays were performed using the 14 eDNA extractions as templates $(2 \mu \mathrm{l}$ of $50 \mathrm{ng}$ per $1 \mu \mathrm{l}$ of eDNA in each $25-\mu 1$ LAMP reaction; $4 \mu \mathrm{l}$ in each $50-\mu 1$ PCR reaction). For the second set of 14 subsamples, needle-like leaves of $C$. deodara were deployed as baits for recovering P. cinnamomi at the baiting duration of $120 \mathrm{~h}$ (Erwin and Ribeiro 1996; Ferguson and Jeffers 1999). DNA was extracted from leaf baits for each subsample using the modified method of Wang et al. (1993). Both Pcinn100006 LAMP and PCR assays were carried out using $14 \mathrm{DNAs}$ extracted from leaf baits as templates. DNA from each subsample was tested twice in both assays. A pair made up of a positive control (purified gDNA of P. cinnamomi isolate Pci1) and an NTC was included in each set of reactions.

\section{Results}

Specificity of the Pcinn100006 LAMP and PCR assays. The Pcinn100006 LAMP assay developed in this study was found to

Table 2. Primers used in the Pcinn100006 loop-mediated isothermal amplification assay

\begin{tabular}{llll}
\hline Primer $^{\mathbf{a}}$ & \multicolumn{1}{c}{ Type of primer } & \multicolumn{1}{c}{ Sequence $\left(\mathbf{5}^{\prime}\right.$ to $\left.\mathbf{3}^{\prime}\right)$} & \multicolumn{1}{c}{ Length $(\mathbf{n t})^{\mathbf{b}}$} \\
\hline F3 & Forward outer primer & GTTCTGCGCGATTTGGTTAG & 20 \\
B3 & Backward outer primer & GCGGATCTTCCGATCTGGTA & 20 \\
FIP & Forward inner primer $($ F1c + F2) & CGAAGGACGAGGTGAAGGTGGACGCCCATACATCACATACG \\
BIP & Backward inner primer (B1c + B2) & AAGGCCGGCTACATGTACTCGTCTCGGGCAAGATGACTTC & 41 \\
LB & Backward loop primer & AACGTGACGCCGGCAACAA & 40 \\
LF & Forward loop primer & TGTTGCCTCCGGGCTGT & 19 \\
\hline
\end{tabular}

a Primers F3 and B3 were also used as the forward and reverse primers, respectively, in the conventional PCR assay of this study.

b nt, nucleotide.

Table 3. Fourteen rhizosphere and soil samples collected in five provinces in China and the Phytophthora cinnamomi detection results in the Pcinn100006 loop-mediated isothermal amplification (LAMP) and conventional PCR assays

\begin{tabular}{|c|c|c|c|c|c|c|c|}
\hline \multirow[b]{3}{*}{ Sample no. } & \multirow[b]{3}{*}{ Location } & \multirow[b]{3}{*}{ Vegetation } & \multirow[b]{3}{*}{ Year } & \multicolumn{4}{|c|}{ Detection result ${ }^{\mathbf{a}}$} \\
\hline & & & & \multicolumn{2}{|c|}{ DNA from soil } & \multicolumn{2}{|c|}{ DNA from leaf baits } \\
\hline & & & & LAMP & PCR & LAMP & PCR \\
\hline 1 & Hefei, Anhui & Pinus sp. & 2014 & + & + & + & + \\
\hline 2 & Hefei, Anhui & Rhododendron simsii & 2014 & + & + & + & + \\
\hline 3 & Liuan, Anhui & Cedrus deodara & 2016 & + & - & + & + \\
\hline 4 & Suzhou, Anhui & Camellia oleifera & 2016 & + & - & + & + \\
\hline 5 & Nanjing, Jiangsu & Pinus sp. & 2015 & + & + & + & + \\
\hline 6 & Yancheng, Jiangsu & Rhododendron simsii & 2015 & + & - & + & + \\
\hline 7 & Xuzhou, Jiangsu & Cedrus deodara & 2016 & + & - & + & + \\
\hline 8 & Tianan, Shandong & Pinus sp. & 2016 & + & + & + & + \\
\hline 9 & Jinan, Shandong & Rhododendron simsii & 2017 & + & - & + & + \\
\hline 10 & Xiamen, Fujian & Pinus sp. & 2016 & + & + & + & + \\
\hline 11 & Zhangzhou, Fujian & Rhododendron simsii & 2016 & + & - & + & + \\
\hline 12 & Kunming, Yunnan & Pinus sp. & 2015 & + & + & + & + \\
\hline 13 & Anning, Yunnan & Rhododendron simsii & 2015 & + & - & + & + \\
\hline 14 (Negative control) & Nanjing Forestry University, Nanjing, Jiangsu & Cedrus deodara & 2017 & - & - & - & - \\
\hline
\end{tabular}

a - , negative; + , positive. 
be specific to $P$. cinnamomi DNA. LAMP reaction mixtures containing gDNAs of $10 P$. cinnamomi isolates collected from Jiangsu, Anhui, and Shandong provinces (Table 1) yielded positive detection of Pcinn 100006 specific to $P$. cinnamomi as the color turned to blue (Fig. 1A). In contrast, LAMP reaction mixtures containing gDNAs of other oomycete or fungal species as well as NTCs remained purple in color (Fig. 1A), indicating lack of detection of the target $P$. cinnamomi sequence. Two repeated LAMP assays yielded identical results against all tested 60 isolates (Table 1).

The PCR assay amplifying an estimated 284-bp fragment within the Pcinn 100006 gene was also found to be $P$. cinnamomi specific. Approximately 280-bp PCR amplicons were found in reactions containing gDNAs of $P$. cinnamomi isolates (Fig. 1B). No PCR amplicons were detected in those using gDNAs of other oomycete or fungal species or of NTCs (Fig. 1B). Two repeated PCR assays yielded identical results.

Sensitivity of the Pcinn100006 LAMP and PCR assays. The Pcinn100006 LAMP assay was found to be 10-fold more sensitive than the conventional PCR assay in detecting gDNA of $P$. cinnamomi. LAMP reaction mixtures $(25 \mu \mathrm{l})$ using $100,10,1$, and $0.1 \mathrm{ng}$ of gDNAs of $P$. cinnamomi isolate Pcil yielded positive detection results (Fig. 2A). No color change was observed in those using gDNAs at lower concentrations $(0.01,0,001$, or $0.0001 \mathrm{ng}$ per reaction) or NTCs (Fig. 2A). In the PCR assay, the minimal detectable DNA concentration was $2 \mathrm{ng}$ in the $50-\mu \mathrm{l}$ reaction ( $1 \mathrm{ng}$ in a $25-\mu 1$ reaction). No PCR amplicons were detected in reactions using DNA template at $0.1 \mathrm{ng}$ or lower (Fig. 2B). Results were identical between two independent repeats of each assay.

Evaluation of the Pcinn100006 LAMP assay using artificial inoculated leaves of $\boldsymbol{C}$. deodara. Identical to the positive control reaction mixture, where $P$. cinnamomi gDNA was used as template, the LAMP mixtures containing DNAs extracted from isolate Pcilcolonized leaves of $C$. deodara changed color to blue, indicating the detection of Pcinn100006 specific to P. cinnamomi (Fig. 3). This finding was consistent between two repeated experiments. Negative control reactions lacked detection in both experiments (Fig. 3).

Detection of $P$. cinnamomi in naturally infested rhizosphere samples. Compared with the negative control $(P$. cinnamomi-free soil sample), P. cinnamomi was detected in leaf baits for all 13

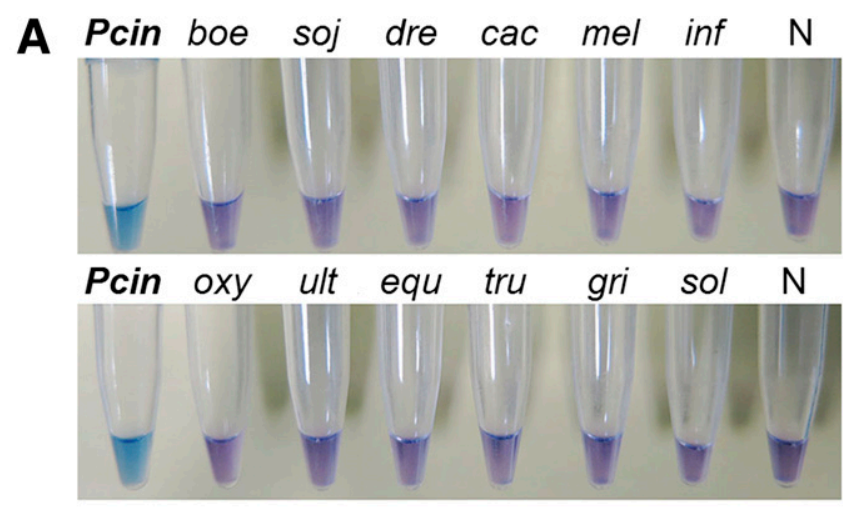

B

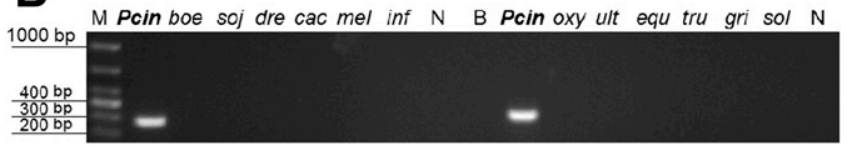

Fig. 1. Specificity of the Pcinn100006 loop-mediated isothermal amplification (LAMP) and conventional PCR assays to Phytophthora cinnamomi. A, LAMP assay. Blue color indicates the detection of $P$ cinn 100006 specific to $P$. cinnamomi. Violet color indicates the lack of detection. B, PCR assay. B, blank; boe, Phytophthora boehmeriae (Pb1); cac, Phytophthora cactorum (C1); dre, Phytophthora drechsleri (CBS 292.35); equ, Fusarium equiseti (Fe1); gri, Magnaporthe grisea (Guy11); inf, Phytophthora infestans (Pi1); M, marker DL1000 (Takara Shuzo); mel, Phytophthora melonis (PMNJHG1); N, nontemplate control; oxy, Fusarium oxysporum (Fo1); Pcin, P. cinnamomi (isolate Pci1); soj, Phytophthora sojae (P6497); sol, Rhizoctonia solani (Rs1); tru, Colletotrichum truncatum (Ct1); ult, Globisporangium ultimum (Gu1).
$P$. cinnamomi-infested rhizosphere samples using either the P cinn 100006 LAMP or PCR assay (Table 3). The LAMP assay using eDNAs directly extracted from rhizospheres also detected $P$. cinnamomi in all 13 samples. In contrast, only 6 of 13 eDNAs were determined as $P$. cinnamomi positive in the conventional PCR assay (Table 3). These findings were consistent between two independent repeats of each assay.

\section{Discussion}

$P$. cinnamomi is one of the most important invasive plant pathogens that affects agricultural and horticultural crops and natural forests worldwide (Erwin and Ribeiro 1996; Zentmyer 1980). Accurate detection of $P$. cinnamomi is prerequisite for implementing effective management measures and successful pathogen eradication. Thus, an ideal detection assay must be sensitive enough to detect low levels of $P$. cinnamomi in both symptomatic and asymptomatic plants as well as environmental samples, such as rhizosphere samples. Additionally, it must be specific to $P$. cinnamomi, because misidentification of relatively low-risk Phytophthora species may lead to unnecessary management and removal of plants, which can be costly. In this study, an LAMP assay was developed for detecting $P$. cinnamomi. $P$. cinnamomi-specific primers were designed to amplify the Pcinn100006 gene, a new target identified from genomic sequence data. This Pcinn100006 LAMP assay was found to be specific to $P$. cinnamomi and more sensitive than a conventional PCR assay. It also has several other advantages compared with PCR-based detection assays.

Several approaches have authenticated that this Pcinn100006 LAMP assay is specific to $P$. cinnamomi. First, genomic sequences of several Phytophthora species were utilized for developing this

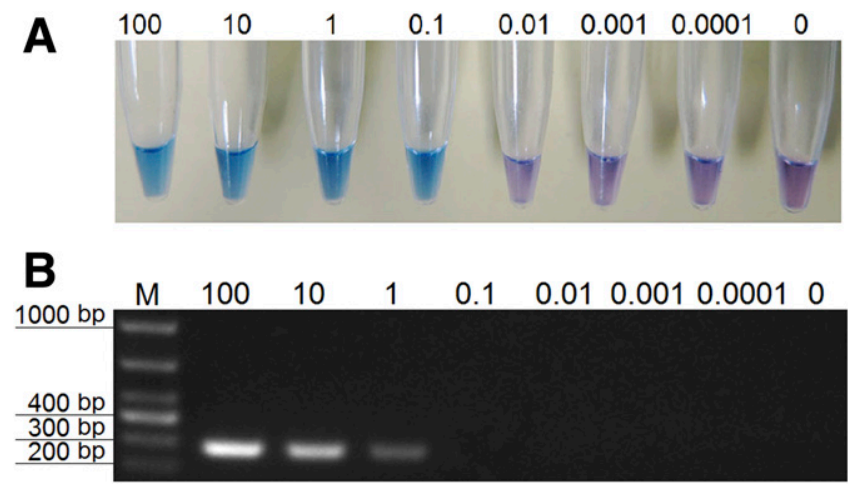

Fig. 2. Sensitivity of the Pcinn100006 loop-mediated isothermal amplification (LAMP) and conventional PCR assays to Phytophthora cinnamomi. Genomic DNAs of $P$. cinnamomi isolate Pci1 $(100,10,1,0.1,0.01,0.001$, and $0.0001 \mathrm{ng}$ in every $25-\mu \mathrm{l}$ reaction mixture) were used as templates in both assays. A, LAMP assay. Blue color indicates the detection of Pcinn100006 specific to P. cinnamomi. Violet color indicates the lack of detection. B, PCR assay. M, marker DL1000 (Takara Shuzo).

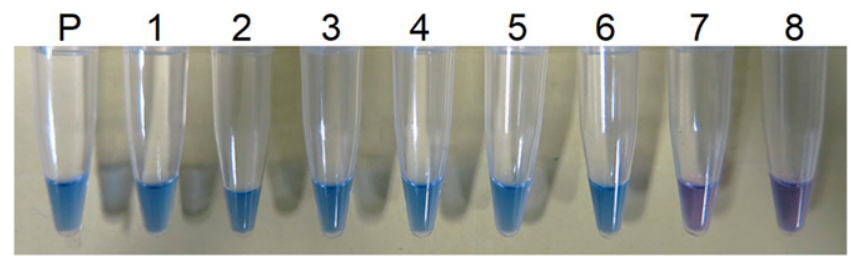

Fig. 3. Detection of Phytophthora cinnamomi in artificially inoculated Cedrus deodara leaves using the Pcinn100006 loop-mediated isothermal amplification assay. Blue color indicates the detection of Pcinn100006 specific to P. cinnamomi. Violet color indicates the lack of detection. $P$ indicates positive control (100 $\mathrm{ng}$ of genomic DNA of $P$. cinnamomi isolate Pci1 as template), 1 to 3 indicate triplicate inoculated samples in experiment 1, 4 to 6 indicate triplicate inoculated samples in experiment 2, 7 indicates negative control (noninoculated leaves) in experiment 1 , and 8 indicates negative control in experiment 2. 
P. cinnamomi-specific LAMP assay. As bioinformatics tools have been increasingly used to identify targets for molecular diagnostics, comparative genomics approaches have been applied for the design of LAMP detection assays of other plant pathogens, such as Erwinia amylovora (Bühlmann et al. 2013a), Xanthomonas species (Bühlmann et al. 2013b; Gétaz et al. 2017; Langlois et al. 2017; Larrea-Sarmiento et al. 2018), Pseudomonas species (Ash et al. 2014; Ruinelli et al. 2017), Calonectria species (Malapi-Wight et al. 2016), and G. ultimum (Shen et al. 2017). In this study, we used a similar approach to identify potential target genes that are unique to $P$. cinnamomi. Second, a $P$. cinnamomi-specific putative gene Pcinn100006 was identified from genomic sequences and analyzed for designing LAMP primers. Traditionally, identifications of Phytophthora species rely on PCR amplification and sequence analysis of several genetic markers, such as the ITS region and $\beta$-tubulin gene (Blair et al. 2008; Cooke et al. 2000; Kroon et al. 2004; Yang and Hong 2018). However, owing to the presence of homologs, primers of these traditional markers may amplify the DNA targets despite sequence variations between species, therefore causing false-positive detection against closely related species (Kunadiya et al. 2017). Third, specificity of this Pcinn100006 LAMP assay was validated by the negative detection results against 50 isolates belonging to other species, including the sister taxon of $P$. cinnamomi, $P$. parvispora (Table 1).

The Pcinn100006 LAMP assay was found to be 10 times more sensitive than a conventional PCR assay using primers F3 and B3 (Fig. 2). It detected $0.1 \mathrm{ng}$ of $P$. cinnamomi gDNA $\left(\sim 1.19 \times 10^{3}\right.$ copies of nuclei) in a $25-\mu l$ reaction. It also detected $P$. cinnamomi in artificially inoculated leaf tissues (Fig. 3) and naturally infested rhizosphere samples at a higher rate than the conventional PCR assay (Table 3). Nevertheless, several previously reported nested PCR and qPCR detection assays of $P$. cinnamomi seem to be 10 to 1,000 times more sensitive (Engelbrecht et al. 2013; Kunadiya et al. 2019; Williams et al. 2009) than the Pcinn100006 LAMP assay in this study. Future studies are warranted to comparatively evaluate the sensitivity of these P. cinnamomi detection assays under the same experimental conditions and further optimize the LAMP assay.

The Pcinn100006 LAMP assay is faster and simpler than any other detection methods of $P$. cinnamomi. First, amplification in the LAMP assay requires a shorter time span of $60 \mathrm{~min}$, whereas a typical 30-cycle PCR takes nearly $2 \mathrm{~h}$. Second, by adding HNB to the reaction, LAMP results can be detected visually as color change (Goto et al. 2009), whereas $\sim 30$-min gel electrophoresis and photography using ultraviolet transilluminators are usually required in conventional PCR assays. Third, this LAMP assay does not require complex instruments, such as a thermal cycler or electrophoresis chamber. LAMP amplification can be performed using a regular laboratory water bath as demonstrated in this study or a block heater. Considering its accuracy, simplicity, and shorter time span, this Pcinn100006 LAMP assay is a promising diagnostic tool to replace conventional PCR-based and culture-dependent assays for high-throughput screening of $P$. cinnamomi in both plant and environmental samples.

\section{Acknowledgments}

The authors thank Dr. Chuanxue Hong at Virginia Tech, U.S.A.; Dr. Bruno Scanu at Università degli Studi di Sassari, Italy,; and Dr. Brett Tyler at Oregon State University, U.S.A., for providing isolates of Phytophthora species that were used in the specificity evaluation of this study. The authors also thank Drs. Danyu Shen and Brett Tyler for providing supports and suggestions on the bioinformatics analyses in this study.

\section{Literature Cited}

Ash, G. J., Lang, J. M., Triplett, L. R., Stodart, B. J., Verdier, V., Cruz, C. V., Rott, P., and Leach, J. E. 2014. Development of a genomics-based LAMP (loopmediated isothermal amplification) assay for detection of Pseudomonas fuscovaginae from rice. Plant Dis. 98:909-915.

Blair, J. E., Coffey, M. D., Park, S. Y., Geiser, D. M., and Kang, S. 2008. A multilocus phylogeny for Phytophthora utilizing markers derived from complete genome sequences. Fungal Genet. Biol. 45:266-277.

Bühlmann, A., Pothier, J. F., Rezzonico, F., Smits, T. H. M., Andreou, M., Boonham, N., Duffy, B., and Frey, J. E. 2013a. Erwinia amylovora loopmediated isothermal amplification (LAMP) assay for rapid pathogen detection and on-site diagnosis of fire blight. J. Microbiol. Methods 92: 332-339.

Bühlmann, A., Pothier, J. F., Tomlinson, J. A., Frey, J. E., Boonham, N., Smits, T. H. M., and Duffy, B. 2013b. Genomics-informed design of loop-mediated isothermal amplification for detection of phytopathogenic Xanthomonas arboricola pv. pruni at the intraspecific level. Plant Pathol. 62:475-484.

Chen, Q. H., Li, B. J., Liu, P. Q., Lan, C. Z., Zhan, Z. X., and Weng, Q. Y. 2013. Development and evaluation of specific PCR and LAMP assays for the rapid detection of Phytophthora melonis. Eur. J. Plant Pathol. 137:597-607.

Cooke, D. E. L., Drenth, A., Duncan, J. M., Wagels, G., and Brasier, C. M. 2000. A molecular phylogeny of Phytophthora and related oomycetes. Fungal Genet. Biol. 30:17-32.

Crandall, B. S., Gravatt, G. F., and Ryan, M. M. 1945. Root disease of Castanea species and some coniferous and broadleaf nursery stocks, caused by Phytophthora cinnamomi. Phytopathology 35:162-180.

Crone, M., McComb, J. A., O'Brien, P. A., and Hardy, G. E. 2013. Survival of Phytophthora cinnamomi as oospores, stromata, and thick-walled chlamydospores in roots of symptomatic and asymptomatic annual and herbaceous perennial plant species. Fungal Biol. 117:112-123.

Dai, T. T., Lu, C. C., Lu, J., Dong, S. M., Ye, W. W., Wang, Y. C., and Zheng, X. B. 2012. Development of a loop-mediated isothermal amplification assay for detection of Phytophthora sojae. FEMS Microbiol. Lett. 334:27-34.

Dick, M. W. 2001. Straminipilous Fungi: Systematics of the Peronosporomycetes, Including Accounts of the Marine Straminipilous Protists, the Plasmodiophorids, and Similar Organisms. Kluwer Academic Publishers, Dordrecht, The Netherlands.

Dong, Z. M., Liu, P. Q., Li, B. J., Chen, G. L., Weng, Q. Y., and Chen, Q. H. 2015. Loop-mediated isothermal amplification assay for sensitive and rapid detection of Phytophthora capsici. Can. J. Plant Pathol. 37:485-494.

Duan, C. H., Riley, M. B., and Jeffers, S. N. 2008. Characterization of Phytophthora cinnamomi populations from ornamental plants in South Carolina, USA. Arch. Phytopathol. Plant Prot. 41:14-30.

Engelbrecht, J., Duong, T. A., and van den Berg, N. 2013. Development of a nested quantitative real-time PCR for detecting Phytophthora cinnamomi in Persea americana rootstocks. Plant Dis. 97:1012-1017.

Erwin, D. C., and Ribeiro, O. K. 1996. Phytophthora Diseases Worldwide. APS Press, St. Paul, MN.

Ferguson, A. J., and Jeffers, S. N. 1999. Detecting multiple species of Phytophthora in container mixes from ornamental crop nurseries. Plant Dis. 83:1129-1136.

Getaz, M., Buhlmann, A., Schneeberger, P. H. H., Van Malderghem, C., Duffy, B., Maes, M., Pothier, J. F., and Cottyn, B. 2017. A diagnostic tool for improved detection of Xanthomonas fragariae using a rapid and highly specific LAMP assay designed with comparative genomics. Plant Pathol. 66:1094-1102.

Goto, M., Honda, E., Ogura, A., Nomoto, A., and Hanaki, K. 2009. Colorimetric detection of loop-mediated isothermal amplification reaction by using hydroxy naphthol blue. Biotechniques 46:167-172.

Hansen, Z. R., Knaus, B. J., Tabima, J. F., Press, C. M., Judelson, H. S., Grünwald, N. J., and Smart, C. D. 2016. Loop-mediated isothermal amplification for detection of the tomato and potato late blight pathogen, Phytophthora infestans. J. Appl. Microbiol. 120:1010-1020.

Hardham, A. R. 2005. Phytophthora cinnamomi. Mol. Plant Pathol. 6:589-604.

Khan, M., Li, B., Jiang, Y., Weng, Q., and Chen, Q. 2017. Evaluation of different PCR-based assays and LAMP method for rapid detection of Phytophthora infestans by targeting the Yptl gene. Front. Microbiol. 8:1920.

Kong, P., Hong, C. X., and Richardson, P. A. 2003. Rapid detection of Phytophthora cinnamomi using PCR with primers derived from the $L p v$ putative storage protein genes. Plant Pathol. 52:681-693.

Kroon, L. P. N. M., Bakker, F. T., van den Bosch, G. B. M., Bonants, P. J. M., and Flier, W. G. 2004. Phylogenetic analysis of Phytophthora species based on mitochondrial and nuclear DNA sequences. Fungal Genet. Biol. 41: 766-782.

Kunadiya, M. B., Dunstan, W. D., White, D., Hardy, G. E. S. J., Grigg, A. H., and Burgess, T. I. 2019. A qPCR assay for the detection of Phytophthora cinnamomi including an mRNA protocol designed to establish propagule viability in environmental samples. Plant Dis. 103:2443-2450.

Kunadiya, M. B., White, D., Dunstan, W. A., Hardy, G. E. S. J., Andjic, V., and Burgess, T. I. 2017. Pathways to false-positive diagnoses using molecular genetic detection methods; Phytophthora cinnamomi a case study. FEMS Microbiol. Lett. 364:fnx009.

Langlois, P. A., Snelling, J., Hamilton, J. P., Bragard, C., Koebnik, R., Verdier, V., Triplett, L. R., Blom, J., Tisserat, N. A., and Leach, J. E. 2017. Characterization of the Xanthomonas translucens complex using draft genomes, comparative genomics, phylogenetic analysis, and diagnostic LAMP assays. Phytopathology 107:519-527.

Langrell, S. R., Morel, O., and Robin, C. 2011. Touchdown nested multiplex PCR detection of Phytophthora cinnamomi and P. cambivora from French and English chestnut grove soils. Fungal Biol. 115:672-682.

Larrea-Sarmiento, A., Dhakal, U., Boluk, G., Fatdal, L., Alvarez, A., StrayerScherer, A., Paret, M., Jones, J., Jenkins, D., and Arif, M. 2018. Development of a genome-informed loop-mediated isothermal amplification assay for rapid and specific detection of Xanthomonas euvesicatoria. Sci. Rep. 8:14298. 
Li, B. J., Liu, P. Q., Xie, S. Y., Yin, R. M., Weng, Q. Y., and Chen, Q. H. 2015. Specific and sensitive detection of Phytophthora nicotianae by nested PCR and loop-mediated isothermal amplification assays. J. Phytopathol. 163:185-193.

Linderman, R. G., and Zeitoun, F. 1977. Phytophthora cinnamomi causing root-rot and wilt of nursery-grown native Western azalea and salal. Plant Dis. Rep. 61: 1045-1048.

Malapi-Wight, M., Demers, J. E., Veltri, D., Marra, R. E., and Crouch, J. A. 2016. LAMP detection assays for boxwood blight pathogens: A comparative genomics approach. Sci. Rep. 6:26140.

McCarren, K. L., McComb, J. A., Shearer, B. L., and Hardy, G. E. S. 2005. The role of chlamydospores of Phytophthora cinnamomi - a review. Australas. Plant Pathol. 34:333-338.

Miles, T. D., Martin, F. N., and Coffey, M. D. 2015. Development of rapid isothermal amplification assays for detection of Phytophthora spp. in plant tissue. Phytopathology 105:265-278.

Mori, Y., Nagamine, K., Tomita, N., and Notomi, T. 2001. Detection of loopmediated isothermal amplification reaction by turbidity derived from magnesium pyrophosphate formation. Biochem. Biophys. Res. Commun. 289:150-154.

Nordberg, H., Cantor, M., Dusheyko, S., Hua, S., Poliakov, A., Shabalov, I., Smirnova, T., Grigoriev, I. V., and Dubchak, I. 2014. The genome portal of the Department of Energy Joint Genome Institute: 2014 Updates. Nucleic Acids Res. 42 (D1):D26-D31.

Notomi, T., Okayama, H., Masubuchi, H., Yonekawa, T., Watanabe, K., Amino, N., and Hase, T. 2000. Loop-mediated isothermal amplification of DNA. Nucleic Acids Res. 28:e63.

Rands, R. D. 1922. Streepkanker van kaneel, veroorzaakt door Phytophthora cinnamomi $n$. sp. Meded Inst Plantenziekt 54:1-53.

Rojas, J. A., Miles, T. D., Coffey, M. D., Martin, F. N., and Chilvers, M. I. 2017. Development and application of qPCR and RPA genus- and species-specific detection of Phytophthora sojae and P. sansomeana root rot pathogens of soybean. Plant Dis. 101:1171-1181.

Ruinelli, M., Schneeberger, P. H. H., Ferrante, P., Buhlmann, A., Scortichini, M., Vanneste, J. L., Duffy, B., and Pothier, J. F. 2017. Comparative genomicsinformed design of two LAMP assays for detection of the kiwifruit pathogen Pseudomonas syringae pv. actinidiae and discrimination of isolates belonging to the pandemic biovar 3. Plant Pathol. 66:140-149.

Scanu, B., Hunter, G. C., Linaldeddu, B. T., Franceschini, A., Maddau, L., and Jung, T. 2014. A taxonomic re-evaluation reveals that Phytophthora cinnamomi and $P$. cinnamomi var. parvispora are separate species. For. Pathol. 44:1-20.
Schena, L., Duncan, J. M., and Cooke, D. E. L. 2008. Development and application of a PCR-based 'molecular tool box' for the identification of Phytophthora species damaging forests and natural ecosystems. Plant Pathol. 57:64-75.

Shearer, B. L., Crane, C. E., and Cochrane, A. 2004. Quantification of the susceptibility of the native flora of the South-West Botanical Province, Western Australia, to Phytophthora cinnamomi. Aust. J. Bot. 52:435-443.

Shen, D. Y., Li, Q. L., Yu, J., Zhao, Y. Y., Zhu, Y., Xu, H., and Dou, D. L. 2017. Development of a loop-mediated isothermal amplification method for the rapid detection of Pythium ultimum. Australas. Plant Pathol. 46:571-576.

Si Ammour, M., Bilodeau, G. J., Tremblay, D. M., Van der Heyden, H., Yaseen, T., Varvaro, L., and Carisse, O. 2017. Development of real-time isothermal amplification assays for on-site detection of Phytophthora infestans in potato leaves. Plant Dis. 101:1269-1277.

Thines, M., and Kamoun, S. 2010. Oomycete-plant coevolution: Recent advances and future prospects. Curr. Opin. Plant Biol. 13:427-433.

Tomlinson, J. A., Barker, I., and Boonham, N. 2007. Faster, simpler, more-specific methods for improved molecular detection of Phytophthora ramorum in the field. Appl. Environ. Microbiol. 73:4040-4047.

Tomlinson, J. A., Dickinson, M. J., and Boonham, N. 2010. Rapid detection of Phytophthora ramorum and $P$. kernoviae by two-minute DNA extraction followed by isothermal amplification and amplicon detection by generic lateral flow device. Phytopathology 100:143-149.

Trzewik, A., Nowak, K. J., and Orlikowska, T. 2016. A simple method for extracting DNA from rhododendron plants infected with Phytophthora spp. for use in PCR. J. Plant Prot. Res. 56:104-109.

Wang, H., Qi, M., and Cutler, A. J. 1993. A simple method of preparing plant samples for PCR. Nucleic Acids Res. 21:4153-4154.

Williams, N., Hardy, G. E. S. J., and O'Brien, P. A. 2009. Analysis of the distribution of Phytophthora cinnamomi in soil at a disease site in Western Australia using nested PCR. For. Pathol. 39:95-109.

Yang, X., and Hong, C. X. 2018. Differential usefulness of nine commonly used genetic markers for identifying Phytophthora species. Front. Microbiol. 9 2334.

Yang, X., Tyler, B. M., and Hong, C. X. 2017. An expanded phylogeny for the genus Phytophthora. IMA Fungus 8:355-384.

Zentmyer, G. A. 1980. Phytophthora cinnamomi and the Diseases It Causes. American Phytopathological Society, St. Paul, MN.

Zhao, W., Wang, T., and Qi, R. D. 2015. Ypt1 gene-based detection of Phytophthora sojae in a loop-mediated isothermal amplification assay. J. Plant Dis. Prot. 122:66-73. 